\title{
IDEOLOGI (DAN) ESTETIKA SENO GUMIRA AJIDARMA: SAKSI MATA DALAM RUANG PERJUMPAAN IDEOLOGIS
}

\author{
Moch. Zainul Arifin
}

Mahasiswa Pascasarjana Ilmu Sastra, Fakultas Ilmu Budaya, Universitas Gadjah Mada

arifin_zain90@yahoo.com

\begin{abstract}
Abstrak
Tulisan ini mencoba menguraikan struktur ideologi Seno Gumira Adjidarma dalam Saksi Mata pada masa otoriter Orde Baru. Pisau analisis yang digunakan dalam penelitian ini adalah teori kritik sastra materialisme Terry Eagleton yang mengasumsikan bahwa teks sastra tidak bertindak pasif, tetapi bertindak aktif menentukan proses produksi dan struktur ideologi yang melingkupinya. Dengan demikian, kritik sastra Eagleton melihat karya sastra dari aspek eksternal dan juga aspek internalnya. Berangkat dari hal itu, bagaimana Saksi Mata menawarkan bentuk kritik yang, tentu ideologis, dihadirkan guna mengguncang kekuasaan absolut Orde Baru? Hasil penelitian menunjukkan bahwa, pertama, struktur ideologi dalam cerpen Saksi Mata meliputi prkatik material eksternal dan internal teks. Aspek eksternal teks merupakan hasil artikulasi dominasi Orde Baru. Untuk itu, Saksi Mata juga tidak luput dari pengaruh mobilisasi Soeharto, akan tetapi Seno dengan Saksi Mata mampu melawan kebijakan tersebut. Kedua, konstruksi internal teks yang sebetulnya ruang perjumpaan dan negosiasi ideologi-ideologi yang ada, Saksi Mata berupaya menunjukkan kengerian totaliter Orde Baru. Akan tetapi, tentu dalam ruang politik yang represif, kritik dalam semangat kemanusiaan, keadilan dan kebebasan berpendapat ditransfor-masi dan dibungkus dalam cerpen Saksi Mata dengan bangunan satire dan khas komedi, sekaligus mengungkapkan kengeriannya.
\end{abstract}

Kata Kunci: Struktur Ideologi, Estetika, Terry Eagleton

\section{Abstract}

This paper attempts to elaborate on the ideological structure of Seno Gumira Adjidarma in the Saksi Mata in the authoritarian period of the New Order. The knife of analysis used in this research is Terry Eagleton's materialism literary criticism theory which assumes that the literary text does not act passively, but acts actively to determine the production process and the ideological structure that surrounds it. Thus, Eagleton's literary criticism sees literary works from external aspects as well as internal aspects. Departing from that, how does Saksi Mata offer a form of criticism which, of course ideological, is presented to shake the absolute power of the New Order? The results of the study show that, first, the ideological structure in the short story of Saksi Mata includes the external and internal material principles of the text. The external aspect of the text is the result of the articulation of the domination of the New Order. For this reason, Saksi Mata also did not escape the influence of Soeharto's mobilization, but Seno and Saksi Mata were able to fight the policy. Second, the internal construction of the text which is actually the space for meeting and negotiating existing ideologies, Saksi Mata attempted to show the totalitarian horror of the New Order. However, of course in a repressive political space, criticism in the spirit of humanity, justice and freedom of opinion is transformed and wrapped up in short stories of Saksi Mata with satire and comedy-style buildings, as well as expressing their horror.

Keywords: Structure of Ideology, Aesthetics, Terry Eagleton 
Saksi mata itu datang tanpa mata

(Seno Gumira Adjidarma)

\section{PENDAHULUAN}

Secara historis, kritik modern lahir dari suatu perjuangan melawan negara absolut. Sebagaimana Marxis klasik melihat prosedur kritik secara symptomatic, atau bentuk pembacaan terhadap gejala yang disembunyikan sehingga bertujuan untuk menyadari dan memeranginya. ${ }^{1}$ Akan tetapi, kritik tersebut lambat laun melemah-atau bahkan tergerus-ketika dirangkum dalam industri kebudayaan. Sehingga kritik ideologi yang diperjuangkan tersebut berjumpa dengan ideologi dominan justru diokupasi yang akhirnya tidak mampu merekognisi keadaan yang sebenarnya dan malah larut dalam bualan dominasi. Apabila ditarik dalam ranah kesusateraan, khususnya dalam konteks kesusasteraan Indonesia, timbul sebuah pertanyaan, mampukah sastra itu berdiri di atas ideologinya sendiri dengan mengandaikan salah satu fungsinya sebagai agen emansipasi di dalam kungkungan pemerintahan Orde Baru yang otoriter. Cahaya harapan itu ternyata masih ada dalam penjabaran Terry Eagleton tentang teks sastra yang, menurutnya, tidak bertindak secara pasif, akan tetapi secara aktif menen-tukan proses produksi dan struktur-struktur ideologi yang membentuknya. ${ }^{2}$ Dengan demikian, lalu bagaimana karya sastra menawarkan bentuk kritik yang, tentu ideologis, dihadirkan guna mengguncang kekuasaan absolut negara? Berangkat dari pertanyaan inilah tulisan ini akan melakukan pembacaan terhadap cerita pendek Saksi Mata karya Seno Gumira Ajidarma (selanjutnya ditulis Seno)—sebagai kasus-yang lahir secara kontroversial dalam akhir ruang politik totaliter Orde Baru Soeharto.

Disadari ataupun tidak, setiap karya sastra yang tercipta pada dasarnya dipengaruhi oleh ideologi yang menjadi latar belakang karya tersebut. Hal ini senada dengan Karl Marx bahwa sastra bersifat ideologis sekaligus berada dalam lingkaran ideologi. ${ }^{3}$ Dengan demikian, muara persoalannya ialah perjumpaan ideologi dalam relasi-relasi antara teks dan realitas. Akan tetapi, kajian terhadap

\footnotetext{
${ }^{2}$ Lihat Terry Eagleton, Criticism and Ideologi: A Study in Marxist Literary Theory, (New York: Verso, 1998), hlm. 44-101.
}

${ }^{1}$ Lihat Terry Eagleton, The Function of Criticism, (New York: Verso, 1983), hlm. 1.

${ }^{3} \mathrm{lbid}, \mathrm{hlm} .80$ 
sastra sebelumnya dan pada umumnya hanya berkutat pada pembacaan yang tidak lebih dari sekadar upaya memaknai suatu karya yang telah selesai dan siap untuk dikonsumsi. Dengan kata lain ungkapan tersebut mengandaikan bahwa karya sastra tercerabut dari akar persoalan sosio-historis masyarakatnya. Pembaca-an tersebut melupakan relasi antara sastra dengan faktor-faktor lainnya, se-perti produksi, lembaga penerbitan, pendidikan dan lainnya. Untuk meng-hindari pembacaan seperti itu, tulisan ini akan berupaya melakukan pemba-caan terhadap Saksi Mata melalui gagasan kritikus sastra Marxis asal Inggris Terry Eagleton yang menawarkan pembacaan karya sastra yang harus dipahami sebagai 'praktik material' yang disebut dengan istilah kritik materialistik. Hal ini ditegaskan Eagleton bahwa teks sastra bukanlah ekspresi ideologi, bukan juga ideologi ekspresi kelas sosial, akan tetapi teks lebih tepat dikatakan sebagai produksi ideologi tertentu. ${ }^{4}$ Untuk itu kajian teks sastra seharusnya meliputi aspek-aspek eksternal dan internal teks. ${ }^{5}$ Aspek-aspek

\footnotetext{
${ }^{4}$ Gregory Castle, The Blackwell Guide to Literary Theory. (Malden USA: Blackwell Publishing, 2007), hlm. 108.

${ }^{5}$ Terry Eagleton, Criticism and Ideologi: A Study in Marxist Literary Theory, (New York: Verso, 1998), hlm. 44-63.
}

eksternal mencakup konstituenkonstituen ideologi, yakni corak produksi umum, ideologi umum, corak produksi sastra, ideologi kepengarangan, dan juga ideologi estetik. Maka, dapat diasumsikan bahwa teks sastra merupakan produksi interaksi unsurunsur tersebut. Sedangkan aspek internal merujuk pada ideologi teks yang ditransformasikan dari unsur-unsur eksternalnya.

\section{METODE}

\section{Rancangan Penelitian}

Penelitian ini menggunakan pendekatan pragmatik di mana pendekatan ini memberikan perhatian utama terhadap pembaca. ${ }^{6}$ Pendekatan ini dipilih sebab paradigma dari pembacaan materialistik Terry Eagleton berkenaan dengan cara pembacaan yang tidak hanya melihat karya sastra sebagai produk karya semata, tetapi terdapat pengaruh eksternal yang juga menjadi faktor penting dalam terciptanya karya sastra tersebut.

Sedangkan metode yang digunakan dalam penelitian ini adalah metode kualitatif. Di mana metode

\footnotetext{
${ }^{6}$ Ratna, Nyoman Kutha. 2006. Teori, Metode, dan Teknik Penelitian Sastra. Yogyakarta: Pustaka Pelajar., hlm. 71.
} 
kualitatif merupakan suatu cara atau langkah-langkah yang memanfaatkan penafsiran dengan menyajikannya dalam bentuk deskripsi. ${ }^{7}$ Dalam peneli-tian ini, data yang digunakan berbentuk deskriptif bukan angka-angka, namun mengutamakan kedalaman penafsiran terhadap narasi dan interaksi antar konsep yang sedang dikaji.

\section{Sumber Data dan Data Penelitian}

Sumber data yang digunakan dalam penelitian ini diperoleh dari sebuah cerpen berjudul Saksi Mata yang berada dalam antologi cerpen berjudul Saksi karya Seno Gumira Adjidarma dengan sampul berwarna putih dan terdapat seorang terduduk tampak tersiksa di atas kursi. Cerpen tersebut berjumlah 10 halaman A5. Cerpen ini sebenarnya pertama kali dimuat dalam koran Suara Pembaruan 1992.

\section{Teknik Pengumpulan Data}

Teknik pengumpulan data yang digunakan dalam penelitian ini merupakan teknik baca catat. Teknik pengumpulan data pada dasarnya adalah seperangkat cara atau teknik perpanjangan dari indera manusia karena tujuan- nya adalah mengumpulkan fakta-fakta empirik yang terkait dengan masalah penelitian. ${ }^{8}$ Berdasarkan hal tersebut, teknik pengumpulan data dalam penelitian ini dilakukan sebagai berikut.

a. Peneliti melakukan pembacaan dari awal sampai akhir cerpen Saksi Mata karya Seno Gumira Adjidarma secara berulang untuk memperoleh gambaran keseluruhan mengenai cerpen tersebut.

b. Peneliti merumuskan masalah penelitian berdasar kecenderungan masalah yang terdapat cerpen Saksi Mata karya Seno Gumira Adjidarma.

c. Peneliti membaca teori maupun konsep yang digunakan penelitian untuk membedah dan membahas masalah penelitian.

d. Mencatat data dengan cara memilih beberapa kutipan cerpen Saksi Mata karya Seno Gumira Adjidarma berupa kata, frasa, klausa, kalimat maupun paragraf yang merujuk pada rumusan masalah.

\footnotetext{
${ }^{7}$ Ibid., hlm. 46.
}

\footnotetext{
${ }^{8}$ Lihat Faruk. 2012. Metode Penelitian Sastra. Yogyakarta: Pustaka Pelajar., hlm. 24.
} 
e. Mengadakan pemilihan dan pemilahan bagian-bagian dari penelitian yang dianalisis.

\section{Teknik Analisis Data}

Teknik analisis data menggunakan teknik analisis deskriptif. Teknik analisis deskriptif digunakan untuk mendeskripsikan makna data sehingga menimbulkan kejelasan dan pemahaman bagi pembaca. ${ }^{9}$ Sedangkan instrumen yang digunakan untuk analisis data dalam penelitian ini ialah tabel klasifikasi. Teknik ini digunakan untuk mengklarifikasikan data yang ada dalam cerpen Saksi Mata karya Seno Gumira Adjidarma.

\section{Hasil Pembahasan}

Dalam pengertian Eagleton dapat disebut bahwa karya sastra, dalam hal ini cerpen Saksi Mata karya Seno Gumira Ajidarma, merupakan hasil produksi dari interaksi dan artikulasi aspek-aspek eksternal, yang tentu meru-juk pada konstituen-konstituen ideologi Indonesia pada masa Otoriter Orde Baru Soeharto. Di dalam konstituen eksternal ini terdapat Corak Produksi Umum, Ideologi Umum, Corak Produksi Sastra,

\footnotetext{
${ }^{9}$ Lihat Supratno. 2010. Sosiologi Seni Wayang Sasak Lakon Dewi Rengganis dalam Konteks Perubahan Masyarakat di Lombok. Surabaya: Unesa University Press., hlm. 76.
}

Ideologi Kepengarangan, dan Ideologi Estetik. Maka, dapat diasumsikan bahwa teks sastra merupakan produksi interaksi unsur-unsur tersebut. Sedang-kan aspek internal merujuk pada ideologi teks yang ditransformasikan dari unsur-unsur eksternalnya. Di da-lam aspek-aspek eksternal maupun internal tersebut tulisan akan meng-analisis cerpen Saksi Mata karya Seno Gumira Ajidarma.

\section{Sekilas Corak Produksi Umum Orde Baru}

Corak Produksi Umum (CPU) adalah kesatuan beberapa kekuatan dan relasi sosial produksi material. ${ }^{10}$ Kekuatan produksi tersebut dapat dimengerti sebagai bahan, alat, dan teknik produksi. Sedangkan relasi sosial produksi tersebut adalah posisi yang menunjukkan hubungan seseorang dengan unsurunsur kekuatan produksi dan hubungan yang mengatur interaksi orang atau pihak yang terlibat dalam proses produksi. Komponen CPU ini tidak bisa dipisahkan dengan kondisi ekonomi yang menjadi basis kekuatan produksi, seperti alat, bahan dan teknik produksi.

Sekilas memotret konteks Indonesia pada masa Orba di mana didomi-

\footnotetext{
${ }^{10}$ lbid., hlm. 45.
} 
nasi oleh kekuasaan presiden Soeharto,

CPU Indonesia bergerak dari suatu masyarakat miskin, sebagian besar berbasis ekonomi agrikultur pada pertengahan enam puluhan, pertama kali ke 'sebuah rezim yang diatur oleh kepentingan kelompok militer bayaran' pada tahun tujuh puluhan, dan kemudian menuju suatu negara kesatuan yang didominasi oleh industrialisasi yang luas dan perdagangan konglomerat di akhir delapan puluhan. ${ }^{11}$ Konglomerasi ini, khususnya Cina, menyebabkan distorsi ekonomi dan kesenjangan sosialbayangkan saja empat konglo-merat Cina kekayaannya setara dengan 100 juta orang miskin-apalagi Soehar-to melahirkan UU penanaman modal menjadikan pengusaha Cina semakian menguat sebab keberadaan militer sebagai kolega mereka. Dari sini dapat ditarik ke dalam formasi sosial masyarakat ke dalam kelas-kelas sesuai kepentingannya, yakni kelas masyarakat biasa, kelas pengusaha (Cina) dan kelas elit negara dan juga kelas urban. Dengan berpihaknya elit pemerintah ke perusahaan besar (asing), hal ini mengakibatkan semakian maraknya industriindustri sehingga relasi-relasi sosial-

\footnotetext{
11 Harry Aveling, Rahasia Membutuhkan Kata: Puisi Indonesia 1966-1998, (Indonesia Tera: Magelang, 2001), hlm. xxxi.
}

ekonomi menjadi sempit dengan terpusat pada dunia industri besar, yang memaksa harga jual tinggi, kesenjangan sosial melebar, kebutuhan akan barang mentah ke barang jadi lebih tinggi hingga tenaga kerja yang diperlukan juga banyak akhirnya masyarakat berbondong-bondong masuk ke dunia industri.

\section{Ideologi Umum:}

\section{Doktrin Pembangunan dan Stabilitas Politik}

Eagleton mendefinisikan ideologi umum sebagai segenap wacana yang relatif koheren tentang nilai, representtasi, dan keyakinan yang diwujudkan dalam perangkat material dan hubungan konkret dari subjek-subjek individu dengan kondisi sosialnya untuk menjamin salah persepsi atas kenyataan sesungguhnya yang memberikan sumbangan kepada reproduksi relasi sosial dominan. ${ }^{12}$ Hal tersebut dapat dijumpai pada masa Soeharto tentang ideologi yang menegaskan kepatuhan ke suatu negara tetapi non-politis, yaitu terkait rentang formulasi publik dengan dengungan doktrin Pancasila, pemba-

\footnotetext{
12 Lihat Terry Eagleton, Criticism and Ideologi: A Study in Marxist Literary Theory, (New York: Verso, 1998), hlm. 54.
} 
ngunan (developmentalism) dan pengawasan aktif terhadap komunitas melalui sejumlah aparat negara yang menindas, termasuk militer, angkatan kepolisian dan sistem hukum. Upaya tersebut guna mengha-silkan individu-individu yang, tentu tanpa sadar, ikut berperan aktif dalam CPU ekonomi dan sosial di bawah naungan kendali presiden dan elit pemerintahan. Sarana pembentukan individu secara khusus berupaya memproduksi satu gender manusia yang disiplin dan berperan aktif dalam Corak Produksi Umum ekonomi dan saosil di bawah naungan kendali predisen dan elit pemerintahan terkait. Namun,

Ideologi umum tersebut tidak serta merta menjadi ideologi tunggal yang dianut oleh seluruh lapisan masyarakat, akan tetapi ideologi yang mendominasi dari rangkaian ideologi yang terdapat dalam formasi sosialekonomi.

\section{Corak Produksi Sastra:}

Antara Suara Pembaruan dan Jakarta

\section{Jakarta}

Corak Produksi Sastra (CPS) dimengerti sebagai kesatuan beberapa kekuatan dan relasi sosial produksi sastra dalam formasi sosial tertentu. ${ }^{13} \mathrm{Di}$

\footnotetext{
13 lbid., hlm. 45.
}

dalamnya terdapat komponen produksi tertentu, seperti media, pener-bitan, distribusi, pertukaran dan kon-sumsi. CPS mengikuti perubahan konglomerasi dalam CPU, penulisan semakin tidak berbasis pada publikasi majalah kalangan sendiri dan pener-bitanpenerbitan kecil, tetapi sebalik-nya, semakin bergantung pada surat kabar dan majalah negara atau yang pro negara. Dengan demikian, CPS dominan akan memaksa CPS lainnya ke dalam posisi lemah.

Majalah Jakarta Jakarta, tempat dimana Seno berkerja sebagai Redaktur Pelaksana, cenderung ketakutan ketika Seno memberitakan kesaksiannya tentang insiden Dili, Timor Timur 1991 sehingga Seno dipecat dari majalah tersebut. Dengan diberhentikannya Seno, terlihat ideologi umum, yang diproduksi dari CPU, dengan sendirinya menghasilkan penerbitan majalah yang terpasung tirani atau pro kekuasaan. ${ }^{14}$

Tidak kehilangan akal, akhirnya Seno menuliskan kesaksiannya tersebut dalam cerpen Saksi Mata yang pertama kali dipublikasikan oleh Harian Suara

14 Dalam sebuah pengantar buku antologi Saksi Mata edisi kedua, Seno menuliskan bahwa mereka adalah wajah-wajah pencari selamat. Apalagi secara tegas dari awal pengantarnya, Seno menyatakan apabila buku Saksi Mata terbit kedua kalinya, majalah Jakarta Jakarta sudah tidak terbit lagi. 
Pembaruan 1992. Dari sini tampak bahwa kehadiran karya sastra tidak lahir dari produk imajinasi semata, tetapi sebenarnya juga sebuah produk interaksi rumit serangkaian faktor. Eagleton menyebut penulis sebagai produsen yang harus berurusan dengan bahan-bahan mentah yang ada, lalu memilih dan menggunakan bahasa serta kon-vensi sastra, dialog dengan sumber-sumber faktual maupun tekstual, hingga menentukan media serta target pembaca. ${ }^{15}$ Dalam tahap ini produsen, dalam hal ini penulis, sudah berada dalam relasi tarik-menarik. Sehingga Seno tidak otonom secara total, tetapi menentukan dan ditentukan oleh bahan-bahan yang dihadapi hingga lebih jauh sampai pada proses produksi, distribusi sampai konsumsi. Lebih jauh lagi, produksi karya sastra era-80 an akibat dari depolitisasi kekuatan dominan yang represif, akhirnya kebanyakan tematema yang diusung soal percintaan tanpa melihat realitas sosial yang ada. Melihat kenyataan ini, Saksi Mata berbicara lain, yakni tentang hak asasi dengan bungkusan satire dan komedi.

\section{Ideologi Kepengarangan Seno}

15 Lihat Terry Eagleton, Marxisme and Literary Criticism, (New York: Methund\&co.Ltd, 1976), hlm. 26.
Ideologi kepengarangan merupakan efek cara pandang dengan menyisipkan biografinya ke dalam ideologi umum, dan terlalu ditentukan oleh serangkaian faktor yang berbeda, semisal kelas sosial, gender, kebang-saan, agama, wilayah geografis dan sebagainya. ${ }^{16}$ Hubungan antara ideologi umum dan ideologi kepengarangan cenderung homologi efektif, korespondensi, ketidaksinambungan sosial atau bahkan kontradiksi tajam. Pembentukan ideologi kepengarangan Seno tidak bisa dipisahkan dari ideologi umum Orde Baru. Pembentukan keduanya dapat berpola reproduktif dan kontradiktif.

Di awal Orde Baru, Ideologi Kepengarangan berpartisipasi penuh dalam Ideologi Umum melalui fokus utamanya dalam upaya legitimasi perubahan politik, dimulai dari pemerintahan Soekarno menuju ke Soeharto, dan menjadi tempat yang sesuai dengan kekuasaan militer di dalam struktur sosio-ekonomi dan politik. Ketika kebebasan berpendapat ditekan oleh negara melalui opini tahun 1974, para penulis mencari semacam berbagai pembenaran seperti dapat dipandang sebagai oposisi bagi kenyamanan totalitarisme. Terdapat oposisi terbuka dalam bersastra,

\footnotetext{
16 Ibid., hal. 58
} 
seperti W. S Rendra dan Wiji Thukul yang terang-terangan mengkritisi Orde Baru. Ada juga oposisi yang lebih estetis dalam berkarya yang menga-baikan Ideologi Umum dengan kembali pada Ideologi Estetik yang dibatasi secara hari-hati dalam bahasa murni, seperti Sutardji, Afrizal Malna dan nantinya Seno sendiri termasuk juga di dalamnya. Dan di sini imajinasi sastra lebih bervariasi mulai dari neo-romantisme, absurdisme hingga simbo-lisme.

Secara biografis, Seno sendiri, yang lahir di Boston 1958, adalah seorang putra dari Prof. Dr. Sastroamidjojo, guru besar FMIPA UGM. Berbeda dengan ayahnya, Seno lebih suka hidup bebas. Selepas SMP, dirinya tidak mau sekolah dan ingin mengembara hingga akhirnya dipaksa pulang oleh sang Ibu dan melanjutkan pendidikannya di SMA Kolese De Britto yang boleh tidak memakai seragam. Seno lebih senang bergumul dengan komunitas anak jalanan yang suka tawuran dan pernah juga ikut teater. Pada usia 19 tahun, Seno bekerja sebagai wartawan, menikah dan kuliah di Institut Kesenian Jakarta jurusan Sinematografi. Seno terinspirasi Rendra yang santai, bisa bicara, hura-hura, nyentrik, rambut gondrong dan bisa mengkritik pemerintah. ${ }^{17}$ Sebagai war-tawan, Seno berpindah-pindah dari media satu ke media lainnya, sambil tetap menulis cerita. Seno adalah Redaktur Pelaksana majalah Jakarta Jakarta sampai 1992 karena memberi-takan insiden Dili di majalah itu. Sedangkan dalam bersastra nampaknya Seno lebih menekankan pada aspek pembawaan imajinasi dan bahasa yang digunakan sehingga cenderung dapat lolos dari pengawasan Ideologi Umum.

\section{Ideologi Estetik: Semangat}

\section{Kemanusiaan Jurnalisme Sastra}

Adalah wilayah estetik spesifik dari ideologi umum yang diartikulasikan dengan wilayah lainnya seperti etika, agama, dan hubungannya dengan dominasi dan subordinasi yang pada akhirnya ditentukan oleh corak produksi umum. ${ }^{18}$ Akibat dari pengawasan represif dari negara dan politik stabilitas, garda depan dari karakteristik sastra era80 adalah banyaknya roman percin-taan dan puitikanya bercorak spiritual religius yang lebih simbolisme menga-baikan kontemplasi sosial, serta ada juga oposisi

\footnotetext{
${ }^{17}$ Wikipedia, biografi Seno Gumira Ajidarma https://id.m.wikipedia.org/wiki/Seno_Gumira_Aji darma

${ }^{18}$ Lihat Terry Eagleton, Criticism and Ideology: a Study in Marxist Literary Theory, (New York: Verso, 1998), hlm. 60.
} 
terbuka seperti Rendra dan Wiji Thukul dengan bahasa lugas dan kembali pada persoalan sosial. Nah, Seno, yang juga terinspirasi Rendra, tampaknya menggunakan bentuk ini dengan diramu dalam genre, imajinasi dan bahasa metaforis yang mengena dengan bentuk yang berbeda yakni cerita pendek. Seolah-olah hendak lebih mengkonkretisasi persoalan. Seno lebih bergerak pada cerpenb-cerpen fakta jurnalistiknya dengan mengirimkan cerpen-cerpen tersebut ke berbagai koran nasional, Saksi Mata salah satunya. Walau tetap menyembunyikan fakta telanjang yang ingin sebenarnya diungkap, di sini Seno juga mampu menghindari Self-censorship para redaktur media massa. ${ }^{19}$

Sebagian besar jurnalis sastra mengutamakan narasi atau penyampaian kisah-kisah, dan membangun berbagai adegan. ${ }^{20}$ Dalam jalur pengisahannya, pembaca diajak meloncat-loncat dari jalur satu ke jalur dua dan tiga. Struktur naratif pengisahan terjalin melalui berbagai sekuen adegan naratif primer atau kisah utama, yang meru-

\footnotetext{
19 Lihat Setiawan Santana Kurnia, Jurnalisme Sastra, (Jakarta: Gramedia Pustaka Utama, 2002), hlm. 185.

${ }^{20}$ Ibid., hlm. 133.
}

pakan inti laporan, dan naratif simpangan atau digression, yang meru-pakan kisah-kisah pendukung yang akan melengkapi laporan. Pengarang secara mobile memutar adegan masa kini dan masa lalu yang dilengkapi dengan simpangan-simpangan tersenbut. Seperti dalam Saksi Mata, terdapat bangunan cerita yang mengejutkan di awal kisah, seperti 'Saksi mata itu datang tanpa mata.' Lalu cerita berlanjut dengan pemngakuan sang saksi mata bahwa matanya dicungkil saat dia tidur dalam mimpi. Dengan demikian ada kisah lain dari laporan sang saksi mata, seperti pengakuan 'seragam' yang cenderung menunjukkan segerombolan orang militer. Dari sana cerita menjadi diparodikan tetapi tidak membuang esensi laporan mengerikannya sang saksi mata.

Saksi Mata dengan diksi-diksi 'seragam', 'saksi mata', dan 'darah' tempak hendak menunjukkan kengerian kejadian dari insiden yang melibatkan aparatus negara itu tetapi dengan bangunan dunia imajiner yang lain. Hal ini menunjukkan ideologi estetik Seno diartikulasikan dalam salah satu bentuk konfrontasi terhadap ideologi umum yang dimonitori ideologi totaliterisme. Kendati demikian, di samping ideologi umum dan corak produksi umum, 
ideologi kepengarangan Seno tidak dapat dipisahkan.

\section{Konstruksi Ideologi Teks: Sebuah \\ Perjumpaan dan Negosiasi}

Analisis terhadap ideologi teks dimaksudkan untuk menunjukkan teks tersebut tidak hanya produksi artikulasi dari konstituen-konstituen ideologi, tetapi juga efek dari transformasi, semacam negosiasi dalam ruang perjumpaan imajiner ideologi, yang dilakukan teks atas unsur-unsur ideologi tersebut yang kemudian direproduksi oleh produsen melalui produksi estetik yang menghasilkan ideologi teks. Perlu ditekankan bahwa ideologi teks berbeda dengan ekspresi ideologi kepengarangan, melainkan produk pengolahan estetik atas ideologi umum yang dilakukan oleh pengarang sebagai produsen $^{21}$, dalam hal ini Seno Gumira Ajidarma. Relasi dunia tekstual, dalam hal ini cerpen Saksi Mata karya Seno, dengan realitas historis sebagai produk dan praktik pemaknaan tertentu yang acuannya bersumber dari sejarah benarbenar bersinggungan langsung dengan konstituen-konstituen ideologinya. Sederhananya, konstruksi ideologi dominan bersama konstituen eksternal lainnya

${ }^{21}$ Ibid., 58-59. berjumpa, atau lebih tepatnya dijumpakan, dengan kehendak-kehendak ideologis sang pengarang dan keadaan selingkupnya, bernegosiasi, dan merekonstruksi dunia imajiner dalam teks sekaligus, baik secara eksplisit maupun implisit, terselip ideologi lain, bisa oposisi dari ideologi dominan, dibentuk hingga menjadi teks sastra.

Sepanjang masa berkuasa rezim Orba, pemerintah berhasil menambah kekuasaannya seraya meleyapkan gejala-gejala protes yang efektif dan berkelanjutan terhadapnya. Depolitisasi masyarakat menjadi penting bagi kestabilan pembangunan ekonomi. ${ }^{22}$ Nasionalisme dan Pancasila hanya dua dari sekian faktor utama yang digunakan Orba untuk mendiskreditkan oposisi terhadap kebijakan-kebijakan Negara. ${ }^{23}$ Praktis sejak era-70an, tentu saja, pendapat atau opini disampaikan dengan hati-hati. Sehingga pada era-80an perkembangan sastra secara umum semakin tidak menentu, baik dari segi pengertian maupun karya-karya itu sendiri. Bentuk represif yang keras hingga militer ikut campur dalam kancah

\footnotetext{
${ }^{22}$ Faruk, Pengantar Sosiologi Sastra: Dari strukturalisme Genetik sampai Postmodernisme, Yogyakarta: Pustaka Pelajar, 1994. ${ }^{23}$ Fuller, Andy, Sastra dan Politik: Membaca Karya-Karya Seno Gumira Ajidarma, Yogyakarta: Insist Press, 2011.
} 
politik ini memunculkan sema-ngat antitotalitarime yang kental. Terdapat pihak yang secara terbuka beroposisi melalui sastra, seperti Rendra dan Widji Thukul. Hal ini akhirnya coba diteruskan oleh Seno dalam corak genre yang lain, yakni cerpen.

Tidak sedikit juga sastrawan yang tidak dapat sepenuhnya mempertahankan sikap radikal serupa itu. Ketidaktahuan itu membuat mereka melakukan, misalnya, kompromi dengan juga menulis karya sastra untuk konsumen popular agar diterima dan terbebas dari alienasi. ${ }^{24}$ Seno bersikap berbeda dengan cenderung menggabungkan kedua sastra tersebut, yakni sastra popular dan sastra serius.

Saksi Mata berangkat dari inspirasi Seno, yang menjadi saksi, terhadap insiden Dili Timor Timur 1991 yang di mana Seno memberitakan itu di sebuah majalah Jakarta Jakarta. Tetapi pada akhirnya Seno diberhentikan karena tindakannya memberitakan secara luas ke publik tentang kejahatan kemanusiaan militer di sana. Di dalam Saksi Mata, konstruksi kejadian yang ditampilkan Seno adalah terdapat seorang saksi mata yang kehilangan kedua matanya berjalan menuju ruang

${ }^{24}$ Ibid., hlm. 20. pengadilan dengan tangan meraba-raba ruang udara di depannya. Walau tampak aneh, penggambaran ini cukup memberi efek kejutan sekaligus kengerian dengan diksi-diksi, seperti 'darah', 'lubang mata', 'darah yang mengucur' dan sebagainya. Hal ini dapat dilihat dalam penggalan awalan cerpen ini,

Saksi mata itu datang tanpa mata. Ia berjalan tertatih-tatih di tengah ruang pengadilan dengan tangan meraba-raba udara.

Dari lubang bekas tempat kedua matanya mengucur darah yang begitu merah bagaikan tiada merah yang lebih merah dari merahnya darah yang mengucur perlahan-lahan dan terusmenerus dari lubang mata itu. ${ }^{25}$

Selain suasana kengerian berdarah itu, penggambaran diri Seno sendiri sebagai orang yang bersaksi di depan media masa, melalui berita, di mana Seno cenderung merasa dilema antara menyampaikan kesaksian atau menyimpannya rapat-rapat tetapi tentu itu menghina kemanusiaannya. Akhirnya Seno menyampaikannya dalam

25 Lihat Seno Gumira Ajidarma, Saksi Mata, (Yogyakarta: Bentang Pustaka), 2016 hlm. 2. 
bentuk sastra, ${ }^{26}$ namun Seno mampu mengolahnya dalam bentuk satire dan khas komedi, seperti dalam kutipan berikut,

"Ngomong-ngomong, kenapa Saudara diam saja ketika mata Saudara diambil pakai sendok?"

"Mereka berlima, Pak."

"Saudara, kan, bisa teriak-teriak atau melempar barang apa saja . . . kenapa Saudara diam saja?" "Habis, terjadinya dalam mimpi, sih, Pak."27

Walau tak satupun kata Timor Timur diucapkan dalam cerpen tersebut-bahkan dalam edisi antologi-nya dengan 13 cerpen tentang Dili-konteks dari hadirnya cerpen tersebut dapat dipahami kalau itu soal Dili. Cara Seno menyamarkan fakta sesungguhnya dapat dipahami dari situasi politik Orba yang represif. Bahkan dalam pengantar buku antologi Saksi Mata terbitan kedua, Seno menyampaikan seperti ini,

"Hari-hari itu saya memikirkan harga jiwa manusia. Saya menulis cerita dengan semangat perlawanan, untuk melawan

\footnotetext{
${ }^{26}$ Seperti dalam bukunya, Ketika Jurnalisme dibungkam, sastra harus bicara, yang membicarakan kumpulan cerpen Saksi Mata. 27 Seno Gumira Ajidarma, Saksi Mata, (Yogyakarta: Bentang Pustaka), 2016 hlm. 6.
}

ketakutan saya sendiri-dan saya sungguh bersyukur telah mendapat pilihan untuk melakukannya. Penguasa datang dan pergi. Cerita saya masih ada." 28

Insiden Dili yang menyangkut hak asasi manusia yang mulia dinodai dengan pembantaian secara keji terhadap orang-orang yang tidak bersen-jata atau pro-kemerdekaan Timor Leste dengan penembakan membabi buta terhadap mereka. Dalam laporan yang ditulis Paul R. Bartrop, tentara Indonesia menembaki massa dengan berondong senapan otomatis hingga angka korban tewas sebanyak 273 orang. Penembakan itu terjadi di pemakaman Santa Cruz yang dilakukan oleh tentara Indonesia yang terdiri dari pasukan A Brimob 5485, kompi A dan kompi D Batalion 303, dan kompi campuran (dengan menyamar berpa-kaian preman) serta Batalion 744 dan juga kodim $1627 .^{29}$ Seno dengan cerdik mengulas itu dalam bentuk yang simbolis, seperti dalam kutipan cerpen Saksi Mata berikut,

\footnotetext{
28 Pengantar dalam buku antologi cerita pendek Saksi Mata edisi kedua yang diterbitkan Bentang Pustaka pada 2016 dengan tambahan 3 cerita pendek.

${ }^{29}$ Mengenang 25 Tahun Kejahatan Indonesia di Santa Cruz. Reporter Agung H tirto.id.
} 
"Saya tidak sempat meneliti, Pak, habis mata saya keburu diambil, sih."

"Masih ingat pakaiannya barangkali?

"Yang jelas mereka berseragam, Pak.”

Ruang pengadilan jadi riuh kembali. Seperti dengungan seribu lebah. ${ }^{30}$

Sehingga analisis konstruksi teks cerpen Saksi Mata ini menun-jukkan teks berupaya merekons-truksi konstituen ekstenalnya, ditampilkan dan ditransformasikan untuk menampakkan kengerian kekuasaan Orba. Walau dominasi represif kekuasaan selalu menghantui, tetapi itu tidak menghalangi struktur ideologi teks yang menghasilkan semangat kemanu-siaan, keadilan dan pembebasan.

\section{Kesimpulan}

Dengan berpijak pada pembacaan Materialistik Terry Eagleton, tulisan ini berhasil menemukan dua temuan dalam upaya menjawab pertanyaan yang diajukan di awal tulisan, yakni bentuk kritik yang ditawarkan teks sastra di

30 Seno Gumira Ajidarma, Saksi Mata, (Yogyakarta: Bentang Pustaka), 2016 hlm. 4. dalam kungkungan ideologi yang mengeng-kang. Pertama, struktur ideologi dalam cerpen Saksi Mata merupakan praktik material yang meliputi aspek eksternal dan internal teks. Aspek eksternal teks Saksi Mata merupakan hasil artikulasi dominasi kekuasaan Orde Baru di bawah kendali presiden Soeharto yang menerapkan kebijakan mobilisasi dan pengawasan yang ketat. Sastra tidak luput dari pengaruh mobilisasi dan pengawasan, sehingga tema-tema yang dibicarakan acapkali hanya sebatas soal percintaan dan roman picisan yang tercerabut dari persoalan kehidupan masyarakat. Seno yang memberitakan Insiden Dili dalam majalah Jakarta Jakarta langsung diberhentikan sebagai redaktur media tersebut. Ketakutan tentu ada dalam diri Seno tetapi dia memilih melawan melalui sastra, membongkar kenyamanan ideologi dominan dan menyuarakan apa yang patut disuarakan.

Kedua, konstruksi internal teks Saksi Mata, yang sebetulnya ruang perjumpaan dan negosiasi ideologiideologi yang ada, menunjukkan teks berupaya menggambarkan kengerian totaliter Orde Baru. Akan tetapi, tentu dalam ruang politik yang represif, kritik dalam semangat kemanusiaan, keadilan 
dan kebebasan berpendapat ditransformasi dan dibungkus dalam cerpen Saksi Mata dengan bangunan satire dan khas komedi, sekaligus mengungkapkan kengeriannya dengan diksi, 'darah', 'lubang mata', 'darah mengucur', dan sebagainya. Untuk itu, dapat dipahami bahwa semangat kritik melalui karya sastra dalam penjara ideologi totaliter masih beroperasi dengan dua kondisi, di satu sisi keadaan represif memaksanya untuk diam atau mengangkat tema yang mendukung Orba. Di sisi lainnya, kungkungan itu memunculkan semangat pembebasan sehingga akhirnya konstruksi teks terselip semangat keadilan, kemanusiaan dan kebebasan pendapat dengan mampu lolos dari self-censorship para redaktur media massa nasional. Seperti ungkapan Seno, 'Ketika Jurnalisme dibungkam, Sastra harus bicara. Jurnalisme bicara dengan fakta, sastra bicara dengan kebenaran'. Kebenaran yang disampaikan dengan rekonstruksi teks cerpen Saksi Mata, menjadi kunci yang dapat membuka mata pembaca terhadap ketertutupan berita jurnalisme di Indonesia.

\section{Daftar Pustaka}

Ajidarma, Seno Gumira. 1992. Saksi
Mata. Harian Suara Pembaruan: Jakarta.

$$
\text { 2016. Saksi }
$$

Mata. Bentang Pustaka: Yogyakarta.

Aveling, Harry. 2001. Secrets Need

Words: Indonesian Poetry 1966-

1998. Terj. Rahasia Membutuh-

kan Kata: Puisi Indonesia 19661998. Indonesia Tera: Magelang.

Castle, Gregory. 2007. The Blackwell

Guide to Literary Theory.

Malden USA: Blackwell

Publishing.

Eagleton, Terry. 1998. Criticism and

Ideologi: A Study in Marxist

Literary Theory. New York:

Verso.

and Literary Criticism. New

York: Methund\&co.Ltd . 1983. The

Function of Criticism. New York: Verso.

Faruk. 2012. Metode Penelitian Sastra.

Cetakan ke-1. Yogyakarta:

Pustaka Pelajar.

Fuller, Andy. 2011. Sastra dan Politik: 
Membaca Karya-karya Seno

Gumira Ajidarma. Yogyakarta:

Insist Press.

Kurnia, Septiawan Santana. 2002.

Jurnalisme Sastra. Jakarta:

Gramedia Pustaka Utama.

Ratna, Nyoman Kutha. 2006. Teori,

Metode, dan Teknik Penelitian

Sastra. Cetakan ke-1.

Yogyakarta: Pustaka Pelajar.

Supratno, Haris. 2010. Sosiologi Seni

Wayang Sasak Lakon Dewi

Rengganis dalam Konteks Peru-

bahan Masyarakat di Lombok.

Cetakan ke-1. Surabaya: Unesa

University Press.

Wikipedia, Seno Gumira Adjidarma.

https://id.wikipedia/wiki.org/Sen

o_Gumira_Ajidarma 